\title{
HISTORY OF RICHARDSON'S MERLIN IN SASKATCHEWAN
}

C. STUART HOUSTON, 863 University Drive, Saskatoon, Saskatchewan, S7N 0J8 and ADAM SCHMIDT, 329 7th St. East, Saskatoon, Saskatchewan S7H OX2.

The story of Richardson's Merlin began more than 150 years ago. Dr. John Richardson recognized that there were two forms of merlin in the 1820's when he visited northwest Canada as surgeon and naturalist to the first two Arctic exploring expeditions led by Sir John Franklin. He considered the lighter coloured birds on the edge of the plains to be the Merlin, then called Falco aesalon, that he knew so well in Britain. He correctly gave the name of Falco columbarius, Pigeon Hawk, to the darker bird of the northern forests, which had been named by Linnaeus from a South Carolina specimen of Catesby's. ${ }^{33}$

When Robert Ridgway studied the taxonomy of the North American Merlins in 1870, he did not have access to Richardson's female specimen which had been collected on 14 May 1827 at Fort Carlton. ${ }^{34}$ The bird was obviously nesting nearby since there was an egg in the oviduct. Although Ridgway used a specimen from southeastern South Dakota, outside the known breeding range of any race of Merlin, as the "type specimen," he did recognize the priority of Richardson's specimen from Carlton by naming the new, paler subspecies as Falco richardsonii, Richardson's Merlin. Thirty-five years later in 1905 Ridgway himself reclassified it as a subspecies, Falco columbarius richardsonii. ${ }^{2}$

Meanwhile the next naturalist to visit Fort Carlton was Thomas
Blakiston with the Palliser expeditior who in 1858 recorded the first nes ever found of the Richardson's Merlir $3 \mathrm{~m}$ above the ground in a clump c willows and aspen. ${ }^{4}$ The nest with fou eggs and the parent birds wer collected on 25 May 1858. Blakisto assumed incorrectly that the Merli had built the nest; both crows an magpies were present, although bot were much less common than the are today.

Blakiston failed to appreciate tha all of our falcons, like all of our owls take over an appropriate nest sit without building a proper nest struc ture themselves. The Merli elsewhere has been know to us hollow trees and ledges on cliffs, bu in Saskatchewan the Merlin is th falcon equivalent of the Long-eare Owl, taking over crow and magpi nests.

All early writings suggest tha Richardson's Merlins on the grea plains were restricted to wooded rive valleys for nesting. Allen, ${ }^{1}$ Coues $^{8}$ an Grinnell, ${ }^{16}$ in the Dakotas and Mon tana in the 1870's, and Macoun i what is now Alberta and Saskat chewan in 1879 and $1880,{ }^{25}$ eacl found Richardson's Merlin restricte to the wooded river valleys.

H. Roy Ivor, as a lad of 13 years found the second recorded nest of th Merlin in western Canada, in a popla on 20 May 1883. A detailed surveyor' map of that year in the Saskat chewan Archives showed the onl sizeable clumps of trees in the town 
G. A. Fox, 10 July 1961). In a coulee draining into the valley $10 \mathrm{~km}$ west of Fort Qu'Appelle, R. H. Carter, Jr., banded four young Merlins on 23 July 1923 and another four on 5 July 1925 , but identified only the latter as being definitely of the pale subspecies. ${ }^{6}$ The senior author (CSH) banded two young Merlins in a magpie nest in willows in the Arm River Valley west of Regina Beach on 7 July 1957. In 1959, the Saskatchewan Falconry Club found a pair on territory in the valley near Craven, and a pair at a nest near the valley at Tregarva.

Along the South Saskatchewan River south of Eatonia and Kindersley, Glen A. Fox found three Merlin nests in 1958 and one in 1959. Maher and his students found single nests in coulees along the South Saskatchewan River east of Matador in 1967, 1969 and $1972,{ }^{26}$ and in the same area CSH banded 4 young on 22 June 1974 and five and four young $2 \mathrm{~km}$ apart in one coulee on 15 June 1980, all in magpie nests. Further east near Demaine, $\mathrm{CSH}$ banded five young in a magpie nest in a coulee on 17 June 1978.

In Douglas Park, south of the elbow of the South Saskatchewan River, Gary G. Anweiler and John Polson found four pairs of Merlins on territory in 1976. AS found two nests there the next year, one with four young in a crow nest on 24 June and one with five young in a magpie nest on 5 July.

It is not surprising that Richardson's Merlins occur as far northeast as Nipawin, since the habitat along the Saskatchewan River there is similar to that at Carlton. Between 1952 and 1958, Maurice G. Street recorded seven nests in seven years. ${ }^{23}$ After Street ceased banding $\mathrm{CSH}$ banded five and three young in two crow nests on the edge of Nipawin on 1 July 1964. Stan Riome located breeding pairs near Nipawin in 1966, 1967 and two pairs in 1969.
A pair of Merlins nested on ar island in the North Saskatchewar River at Battleford from 1959 through 1962; the pair was present but ap parently not nesting in 1963 (Spence G. Sealy).

The rough topography of the Bic Muddy Badlands is also attractive to Merlins and an intensive study by the Saskatchewan Falconry Association there in 1969 turned up no less thar 10 nests. ${ }^{17}$

The only nesting records of the Merlin from the "parkland" area ir early settlement days are from the Yorkton-Saltcoats area, where Walte Raine visited with Frank Baines a Crescent Lake in the first half of June 1901. A nest with four eggs on 2 June and two nests with five eggs each on 5 June 1901 are in the Chicagd Museum of Natural History (lette from Emmet R. Blake to G. A. Fox, January 1961) and six eggs collected by Raine at Crescent Lake 3 June 1901 are in the Museum of Vertebrate Zoology at Berkeley (letter from R. J Neidrach to G. A. Fox). Finally Edward Arnold collected five Merlir eggs from a crow nest at Crescen Lake on 17 May 1904 (Neidrach tc Fox).

On 2 May 1979 while CSH attendec an interment in the Yorkton cemetery a pair of Merlins acted as though or territory. On 28 June of the next yea he banded five young $9 \mathrm{~m}$ from the ground in a spruce in the same cemetery. One or two territorial pairs have been seen near Good Spiri Lake in recent years.

There is no evidence that Merlins nested elsewhere on the open plains beyond the wooded valleys and some of the rougher and more woodec country mentioned above prior to the 1930 's. R. T. Congdon's studies in the Kinistino-Basin Lake area in May anc June 1902, ${ }^{7}$ and those of J. F. Ferry and R. M. Barnes at the Quill Lakes in 
$1909,{ }^{10}$ did not record a single Merlin. Just north of the Cypress Hills, at Maple Creek, Crane Lake and Bigstick Lake, extensive inyestigations by A. C. Bent, Herbert K. Job and Chester S. Day in June 1905 and by Bent, Louis B. Bishop, Alfred Eastgate and Jonathan Dwight, Jr., in June and July of 1906, recorded no Merlin nests whatever and they collected only two specimens. ${ }^{3}$ As late as May and June of 1932, a Carnegie Museum party studied birds in the Davidson area, between Elbow and -ast Mountain Lake, collecting two apparently non-breeding birds and inding no nests. ${ }^{36}$

Shelterbelts around farms began to each maturity after about $1920 .{ }^{22}$ As many uneconomic farmsites were abandoned by farmers in the 1930's and as the increased numbers of nagpies made more nest sites available, ${ }^{21}$ Merlins undoubtedly occupied new districts where substantial areas of unbroken grassland peristed adjacent to the new nesting opportunities. This was particularly true f the soil was somewhat sandy. Shelterbelts on the plains not too far rom river valleys were probably the nost attractive.

Then in the early 1960's a Merlin "crash" occurred, at least in the Kindersley area. This is the only area where adequate checks were made pefore and during extensive use of fieldrin for grasshopper control beween 1958 and $1964 .^{18}$

When Glen A. Fox began studying Merlins near Kindersley in 1956, they hested commonly in shelterbelts of leserted farms."1 Fox found four hests in 1958, four in 1959 and three n 1960. In 1958, Richard Fyfe firected CSH to a nest $10 \mathrm{~km}$ north and $10 \mathrm{~km}$ east of Kindersley where hree young were banded in a crow hest in a willow.

Merlin eggshells were already pecoming thinner by 1960 , and by
1962 only one of Fox's six Merlin sites remained occupied. ${ }^{12}$ Fox made regular checks of the area in 1963, when no nesting Merlins could be found, and continued to make occasional checks yearly through 1967 , and brief visits in 1972 and 1973. Fyfe also grew up at Kindersley and sporadically visited 15 previous Merlin sites there and from Dodsland to the Alberta boundary through the late 1960's, without finding any nesting birds. These old sites were all visited again by Keith Hodson in 1972, who found none occupied, although he did locate two unsuccessful Merlin nests north of Marengo.

In 1969, CSH began regular banding visits each June and again each July to Ferruginous and Swainson's Hawk nests in and near the large community pastures, which by then contained most of the remaining grassland west of Kindersley. In the first six summers, through 1974, not a single Merlin was heard or seen. In contrast, beginning in 1975, nesting Merlins have been encountered yearly, and have been found nesting more commonly, in the Kerrobert, Rosetown-Biggar and Saskatoon areas. These are tabulated below:

\section{KINDERSLEY AREA:}

1975: 28 June, 3 young in crow nest, Kindersley-Elna (K-E) Community Pasture.

1976: 28 June, 3 young in crow nest, K-E Pasture, $3 \mathrm{mi}$ farther east.

25 July, 3 fledged young from crow nest, edge of Beaufield Pasture.

1977: 17 July, pair on territory, no young located, Community Pasture north of Hoosier.

1978: 24 June, 5 young in magpie nest south of Flaxcombe.

1979: 2 July, 3 young in magpie nest at Hoosier Pasture.

1980: 22 June, 4 young in magpie nest at Hoosier Pasture.

\section{KERROBERT AREA:}

1977: 25 June, 5 young in crow nest (only successful nest of three pairs in a 
$60-\mathrm{km}^{2}$ portion of Mariposa Community Pasture surveyed by AS).

1978: June 22, 2 young in crow nest. June 25, 5 eggs in crow nest, failed by 15 July.

15 July, 4 fledged young from Swainson's Hawk nest. These three nests were in a line, at $1.6 \mathrm{~km}$ intervals, in Mariposa Pasture.

1979: 1 July, 3 nests with 4, 5 and 5 young in Mariposa Pasture and nest with 5 young in Progress Pasture, all in magpie nests, all found by John and Bruce Hanbidge in June.

1980: 21 June, 5 young in magpie nest, Mariposa Pasture (partial search only).

\section{ROSETOWN-BIGGAR AREA:}

Seven years of surveys by the Renaud brothers through 1974 failed to reveal any nesting Merlins. ${ }^{32}$ Gerhard Stuewe then found a pair nesting near Harris in 1976 and in 1977 AS began work on his Sharptailed Grouse study area near Duperow. The following nest records were obtained in the next 4 years:

1977: 28 June, 4 young in magpie nest and 4 in crow nest, near Harris.

28 June, 3 and 5 young, both in magpie nests, near Duperow.

1978: 24 June, 5 young in magpie nest at Harris.

26 June, 5, 5, 4, 2 and 1 young in magpie nests at Duperow, with a sixth nest that failed.

26 June, 3 eggs in crow nest at Richmond Lake south of Biggar, failed but pair still territorial on 15 July.

1979: 5 July, 5 young in magpie nest at Harris; second pair failed.

1 July, 5,5 , and 5 young in magpie nests at Duperow, one nest overlooked.

1 July, 3 young in crow nest at Richmond Lake.

1 July, 3 young in magpie nest near Ruthilda.

1980: $5,5,5$ and 6 young in magpie nests at Duperow and 5 young in magpie nest at Ruthilda, banded by John Polson.

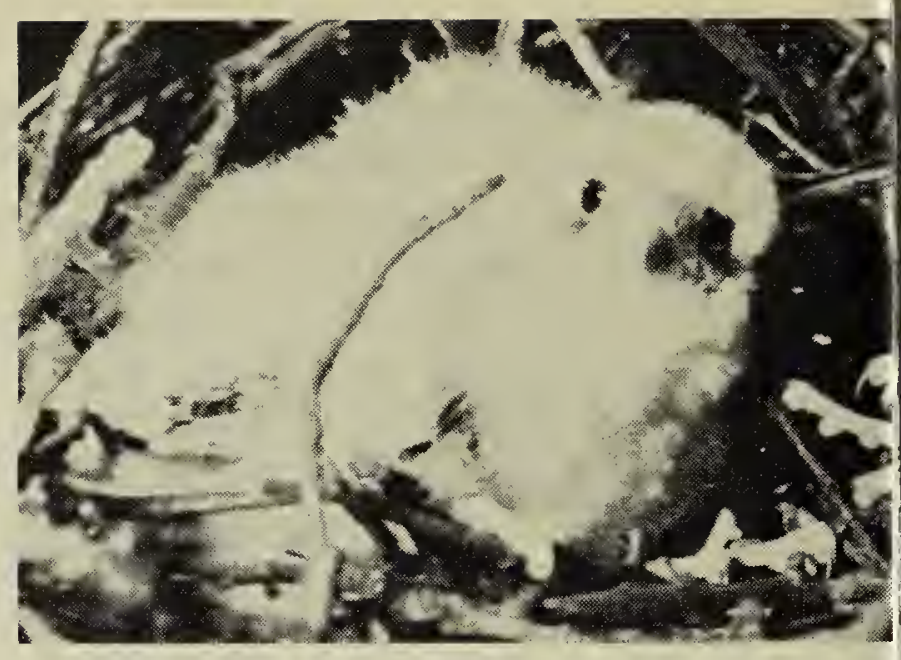

Young Merlin.

C. Stuart Houston

SASKATOON AREA:

The Merlin has probably always been a nesting species along the North Saskatchewan River valley and possibly at selected sites along the South Saskatchewan. On 3 May 1959, J. B. Gollop found a pair at a nest on the river bank at Ceepee siding, $3 \mathrm{~km}$ north of the bridge where Highway 16 crosses the North Saskatchewan. Canoe surveys by Oliphant in 1975 , 1976 and 1977 found Merlins regularly distributed along the next $40 \mathrm{~km}$ of river downstream from the bridge.

Nests away from the river valley have been found $10 \mathrm{~km}$ east of Swanson on 18 June 1965 (R. V. Folker), at the Dundurn military camp in June 1977 and in the Bradwell cemetery in 1979 and 1980.

As a resident of Saskatoon since $1960, \mathrm{CSH}$ has watched with interest the increase of the Merlin as a nesting species within the city. The first nest on record was in the secluded trees of the Labatt's Brewery grounds on the river bank immediately adjacent to the Saskatchewan Crescent residential area. Here a Merlin was seen on a nest high in a tree by Michael $A$. Gollop on 10 May 1963 , and again by Gollop and J. A. Slimmon on 12 May; the tree was not climbed. The next nest was found by Slimmon with young just out of the nest in 
Woodlawn cemetery on 7 July 1970 . Merlins nested at Simpkins market garden along the river bank in 1971 and on 4 July $1972 \mathrm{CSH}$ banded 5 young there in a crow nest in a spruce.

In 1973 , the first nest located in a residential area contained four young in a crow nest $10 \mathrm{~m}$ high in a spruce on Elliott Street, with the young banded on 29 June. Two other Merlin nests that year, one in Woodlawn cemetery and one at the north edge of the University property, both failed.

In 1974, Oliphant took over banding of Merlins within Saskatoon and in 1979 John Polson made this study part of his Master's thesis project. There were at least 7 resident pairs in 1978, at least 10 in 1979 and 15 pairs within the city limits in 1980 .

\section{Discussion}

Richardson's Merlin has always had a somewhat restricted distribution in Saskatchewan initially confined chiefly to wooded river valleys. It probably colonized new grassland territory, taking advantage of the increased numbers of corvid nests that became available, after shelter belts grew to maturity and marginal farms were deserted.

The Merlin suffered a production and population decline in the Kindersley area from 1960 to 1962 and was then essentially absent there until the 1970's. Weekend visits to deserted shelter belts in larger pastures near Kindersley suggest that a minor resurgence has occurred since 1975. However, these sites are occupied more erratically than in areas such as Duperow where pairs consistently nest within $100 \mathrm{~m}$ of their previous sites, year after year. Other former sites nearer Kindersley now have insufficient grassland within the foraging area to support the return of the Merlin. ${ }^{18}$
In his Hanna, Alberta, study area. Keith Hodson found that $95 \%$ of his successful Merlin sites had more than $50 \%$ of their territory in grassland. ${ }^{18}$ Hodson studied air photos of the 15 former Merlin sites in the Kindersley area; between 1956 and 196110 of the 15 territories were more than $50 \%$ grassland, whereas by 1971 only four of the old sites were more than $50 \%$ grassland.

Hodson also documented the increased burdens of biocides which threatened Merlins, and noted the extensive use of dieldrin around Kindersley between 1958 and 1964 . Two eggs from a Merlin nest north of Marengo in 1972 contained 2.78 and 3.24 parts per million of dieldrin; with one exception these were the highest of 166 eggs he tested for this chemical.

At his main study area near Hanna, Hodson found that Merlin egg-shell thinning correlated with decreased productivity and with high levels of DDE in the eggs. Fyfe, Risebrough and Walker also reported that the eggshells were thinnest in Merlins that produced no young, and progressed towards pre-biocide shell thicknesses as they produced two, three or four, and five young, respectively. ${ }^{14}$ There is thus substantial evidence that biocide levels contributed to the decline of the Merlin in the Kindersley area, and that high biocide levels may be associated with changes in behaviour. ${ }^{13}$

On the other hand, we have no evidence concerning Merlin numbers in many areas through the 1960's, although we know that their numbers were maintained at fair levels in the Nipawin mixed forest area to the north and in the Big Muddy badlands to the south.

However widespread the Merlin decline in the 1960's may have been, and it was well documented only for 
Kindersley, we can now say with assurance that the Richardson's Merlin is not now a threatened subspecies. Many of the nests mentioned in this paper were used in Oliphant's 1979 calculations for 47 successful nestings in Saskatchewan between 1970 and 1977, which showed production of 4.0 young per successful nest. ${ }^{30}$ This compares most favourably with pre-1950 reproductive levels of 3.1 to 4.3 young per successful nest.

Further, while the increased numbers of nests found in recent years undoubtedly reflect more the interest and industry of Merlin watchers than an increase in Merlins, it seems undeniable that the species is a new resident of residential streets of cities such as Saskatoon. This influx into cities was made possible largely because of the preceding movement of crows and then magpies as nesting species into these same residential areas. This occurred in Saskatoon between 1968 and $1972 .^{21}$

Smith has documented the high nesting density of Merlins within the Edmonton city limits, estimated at about 20 pairs. He found that they use crow and magpie nests only in trees that are at least 35 years old. ${ }^{35}$

The more consistent presence of large flocks of winter birds, particularly Bohemian Waxwings, which followed maturation of mountain ash and crabapple trees in cities, has made wintering for the Merlin much more feasible in the past $20 \neq$ years. $^{20}$

The oft-repeated statement that certain raptors at the "top of the food chain" are helpful indicators of the quality of our environment is well exemplified by the Richardson's Merlin. Unfortunately the information concerning its past is incomplete and spotty. This interesting race should be monitored more closely in future.

\section{Acknowledgements}

We are grateful to Richard W. Fyfe, J. Bernard Gollop, Wayne C. Harris, Keith Hodson, Lynn W. Oliphant, Wayne E. Renaud, and Guy J. Wapple, for their constructive criticism of an earlier draft of this paper, and for their contribution of unpublished personal observations. Glen A. Fox contributed important unpublished information about early nest records. Fyfe and Hodson provided relevant portions of Hodson's important thesis. Gollop provided access to the observation cards in the Saskatoon bird record scheme. John Polson summarized the results of his Saskatoon nest observations.

'ALLEN, J. A. 1874. Notes on the natural history of portions of Dakota and Montana Territories, being the substance of a report to the Secretary of War on the collections made by the North Pacific Railroad Expedition of 1873. Proc. Boston Soc. Nat. Hist. 17:33-86.

${ }^{2} B A I R D, S$. F., BREWER, T. M. and R. RIDGWAY. 1905. History of North American Birds. Land Birds. 3 vols. Boston: Little, Brown.

${ }^{3}$ BENT, A. C. 1907 and 1908. Summer birds of southwestern Saskatchewan. Auk 24:407-430 and 25:2535.

${ }^{4}$ BLAKISTON, T. 1861-1863. On birds collected and observed in the interior of British North America. Ibis 3:314$320 ; 4: 3-10 ; 5: 39-87$ and 121-155.

${ }^{5}$ BRADSHAW, F. 1926. Report of the Game Commissioner for the year ended April 30, 1926. Regina: King's Printer. $31 \mathrm{pp}$.

${ }^{6}$ CALLIN, E. M. 1980. Birds of the Qu'Appelle, 1857-1979. Regina: Sask. Nat. Hist. Soc. Spec. Publ. 13. 168 pp.

${ }^{7}$ CONGDON, R. T. 1903. Saskatchewan birds. Trans. Wisconsin Acad. 14:569-620.

${ }^{8}$ COUES, E. 1878 . Field-notes on birds observed in Dakota and Montana 
along the 49th parallel during the seasons of 1873 and 1874 . Bull. U.S. Geol. and Geog. Survey Terr. 4:545661.

DIPPIE, G. F. 1895. Nesting of Richardson's Merlin. Oologist 12:135-136.

'FERRY, J. F. 1910. Birds observed in Saskatchewan during the summer of 1909. Auk 27: 185-204.

'FOX, G. A. 1964. Notes on the western race of the Pigeon Hawk. Blue Jay 22:140-147.

${ }^{2}$ FOX, G. A. 1971. Recent changes in the reproductive success of the Pigeon Hawk. J. Wild. Manage. 35:122-128.

${ }^{3}$ FOX. G. A. and T. DONALD. 1980. Organochlorine pollutants, nestdefense behavior and reproductive success in merlins. Condor 82:81-84.

${ }^{4}$ FYFE, R. W., RISEBROUGH, R. W. and WALKER, W. II. 1976. Pollutant effects on the reproduction of the prairie falcons and merlins on the Canadian prairies. Can. Field-Nat. 90:346-355.

${ }^{5}$ GODFREY, W. E. 1950. Birds of the Cypress Hills and Flotten Lake Regions, Saskatchewan. Ottawa: Nat. Museum Canada Bull. 120. 428 pp.

${ }^{6}$ GRINNELL, G. B. 1875. Zoological report. Pp. 79-102 in: Report of a reconnaissance of the Black Hills of Dakota, made in the summer of 1874 , by William Ludlow. Washington: Engineer Dept., U.S. Army.

${ }^{7} H O D S O N$, K. 1972. Research Planning Conference on Peregrines and other birds of prey. Raptor Research News 5:157-158.

${ }^{8}$ HODSON, K. 1976. Some aspects of the nesting ecology of Richardson's Merlin on the Canadian prairies. M.S. Thesis, University of British Columbia.

${ }^{9}$ HOUSEMAN, J. E. 1894. Nesting habits of Richardson's Merlin. Oologist 11:236-237.

HOUSTON, C. S. 1976. Wintertime bird feeding - prairies. Nature Canada 3 (4):3-5, December.

${ }^{21 H O U S T O N}$, C. S. 1977. Changing patterns of Corvidae on the prairies. Blue Jay 35:149-156.

${ }^{22}$ HOUSTON, C. S. 1979. The spread of the Western Kingbird across the prairies, Blue Jay 37:149-157.

${ }^{23}$ HOUSTON, C. S. and M. G. STREET. 1959. The birds of the Saskatchewan River, Carlton to Cumberland. Regina: Sask. Nat. Hist. Soc., Spec. Pub. 3. 205 pp.

${ }^{24}$ IVOR, H. R. 1968. I Live with Birds. Toronto: Ryerson Press. 172 pp.

${ }^{25}$ MACOUN, J. 1903. Catalogue of Canadian Birds, Part II. Ottawa: S. E. Dawson, Queen's Printer. 194 pp.

${ }^{26}$ MAHER, W. J. 1974. Birds: II. Avifauna of the Matador area. I.B.P. Matador Project, Tech. Rep. 58. Saskatoon: University of Saskatchewan. 36 pp.

${ }^{27}$ MITCHELL, H. H. 1923. More notes from Saskatchewan. Condor 25:159-162.

${ }^{26} \mathrm{MITCHELL}, \mathrm{H}$. H. 1924. Birds of Saskatchewean. Can. Field-Nat. 38:101-118.

${ }^{29}$ OLIPHANT, L. W. 1974. Merlins - the Saskatoon falcons. Blue Jay 23:140147.

${ }^{30}$ OLIPHANT, L. W. and W. J. P. THOMPSON. 1979. Recent breeding success of Richardson's Merlin in Saskatchewan. Raptor Research News 12:35-39.

${ }^{31}$ POTTER, L. B. 1930. Bird-life changes in 25 years in southwestern Saskatchewan. Can. Field-Nat. 44:147-149.

${ }^{32}$ RENAUD, W. E. and D. H. RENAUD. 1975. Birds of the Rosetown-Biggar district, Saskatchewan. Regina: Sask. Nat. Hist. Soc., Spec. Publ. 9. 121 pp.

${ }^{33} \mathrm{RICHARDSON}, J$. and W. SWAINSON. 1832. Fauna Boreali-Americana, Vol. II, the Birds. London: John Murray.

${ }^{34}$ RIDGWAY, R. 1870. A new classification of the North American Falconidae, with description of three new species. Proc. Acad. Nat. Sci. Philadelphia 22:138-150.

${ }^{35}$ SMITH, A. R. 1978. The merlins of Edmonton. Alberta Naturalist 8:188-191.

${ }^{36}$ TODD, W. E. C. 1947. Notes on the birds of southern Saskatchewan. Ann. Carnegie Museum 30:383-421. 